\title{
Organic Nutrient Management in Context to Sustainable Fodder Production: A Review
}

\author{
Santosh Onte $^{1}$, Magan Singh ${ }^{1 *}$, V. K. Meena ${ }^{1}$, Sanjeev Kumar ${ }^{1}$, \\ B. L. Meena ${ }^{2}$ and Susanta Dutta ${ }^{1}$ \\ ${ }^{1}$ Agronomy Section, ICAR - NDRI, Karnal (Haryana) -132001, India \\ ${ }^{2}$ Department of Soil Science, ICAR-CSSRI, KARNAL (Haryana) - 132001, India \\ *Corresponding author
}

\section{A B S T R A C T}

The costs of feeding dairy animals can make up to 50-70\% of the total cost of producing milk. Therefore, it is important to find ways of minimizing feed costs to improve the

\section{Keywords}

Organic nutrient

Management,

Panchagavya,

PGPR, FYM,

Fodder Production.

Article Info

Accepted:

24 August 2019

Available Online:

10 September 2019 economic efficiency of any dairy enterprise. Producing economical fodder to feed dairy animals is of great importance to the farming system. Further in India the total feed requirement for the country's livestock population is also increasing rapidly in order to sustain milk production. In the country majority of the farmers are small and marginal who use most of their land for agricultural crop cultivation. But a large number of farmers among them are dairy farmers whose income relies on the milk production of the dairy animals. Therefore, it is important to look at the farm as a whole system and determine whether it is worthwhile to grow more fodder to ensure feed is available for the dairy herd. Imbalanced use of chemicals and second generation problems of green revolution in agriculture has weakened the ecological base in addition to degradation of soil, water resources, food quality, crop productivity and farm profitability especially in cereal based intensive cropping systems in the country especially in North India. Human health hazards and environmental degradation associated with this input intensive cropping system has renewed the interest in the organic cultivation of crops. Global warming led climate changes are further aggravating the agro-ecological imbalance. Hence the current scenario firmly emphasizes the need to adopt eco-friendly agricultural practices for sustainable food production.

\section{Introduction}

In India, the scenario of forage production and utilization presents contrasting picture in comparison to European countries. The present fodder resources in the country can meet only 45 to 50 per cent of the requirement and the magnitude of fodder deficit vary from state to state. At present, the country faces a net deficit of $62.76 \%$ green fodder, $23.46 \%$ dry crop residues and $64 \%$ feeds as a result, crude protein and total digestible nutrients (TDN) deficiency has taken a toll of 28.44 and 24.04 per cent (Anonymous, 2001) and the trend could well continue in the future. The situation is further aggravated due to the 
increasing growth of livestock, particularly that of genetically upgraded animals. The 18th Livestock Census (2009) has placed the country's total livestock population at 495 million and only 4.2 to 4.4 per cent of the country's cropped area remained under fodder crops and there is hardly any scope of expansion because of pressure on agricultural land for food and cash crops. In contrast, European countries like U. K. possess 75.0 per cent of cropped area under forage production (Dar et al., 2006).

Growing fodder for dairy animals in India is not a very popular exercise, especially for small dairy farmers as it is not seen to provide much income. However, it can be produced with very little monetary input and if managed properly can help to provide milk throughout the year, which can be a great money maker! There are many problems associated with fodder production in India due to a poor seed supply chain, the arid climate and a lack of technical information.

Imbalanced use of chemicals and second generation problems of green revolution in agriculture has weakened the ecological base in addition to degradation of soil, water resources, food quality, crop productivity and farm profitability, especially in cereal based intensive cropping systems in the country in general and especially North India. Human health hazards and environmental degradation associated with this input intensive cropping system has renewed the interest in the organic cultivation of crops. Global warming led climate changes are further aggravating the farming situation. Hence the current scenario firmly emphasizes the need to adopt ecofriendly agricultural practices for sustainable food production. Awareness has sprung on the adoption of organic farming as an alternate to modern chemical agriculture (Kannaiyan, 2000). Demand and market for organic produce is growing globally. With increased awareness of organic farming, in addition to the organic manures and biofertilizers as a source of nutrients, many organic formulations like Panchgavya has been advocated and practiced for increasing the yield and quality of food.

Forage quality is defined in various ways, but is often poorly understood. It represents a simple concept, yet encompasses much complexity. Though important, forage quality often receives far less consideration than it deserves. Adequate animal nutrition is essential for high rates of gain, ample milk production, efficient reproduction, and for adequate profits. However, forage quality varies greatly among and within forage crops, and nutritional needs vary among and within animal species and classes. Producing suitable quality forage for a given situation requires knowing the factors that affect forage quality, then exercising management accordingly. Analysing forages for nutrient content can be used to determine whether quality is adequate and to guide proper ration supplementation. In recent years, advances in plant and animal breeding, introduction of new products, and development of new management approaches have made it possible to increase animal performance. However, for this to be realized, there must be additional focus on forage quality.

For sustainable agriculture and to control the hazardous effects of chemical fertilizers, various organic sources of nutrients (FYM, Panchagavya, bio fertilizers, plant growth promoting rhizobacteria (PGPR), green manures etc..) are the best options for Indian agriculture. The organic manure is an ecofriendly, economically viable, ecologically sound and also plays a significant role in the improvement of soil physio-chemical and biological properties of soil. Nutrient supply in crop system should be economically viable, environmentally friendly and socially 
acceptable without affecting the gross plant production. Organically produced food, fodder not only healthier to the environment, it is also fit for the humans, and animals which full fill the needs of healthier food. Now days there is a lot of demand for the organic products like organic ghee, milk, milk products, vegetables, etc., Which we can say secret of the sustainability in the present scenario and for the future generation.

Organic nutrient source gives major emphasis on recovery and maintenance of soil fertility and for sustainable yield. Organic nutrient sources improve the physical, chemical and biological properties of soil and maintain the ecological balance as well as productivity of life supporting systems for the future generations. Organic systems rely on the management of organic matter to enhance the soil fertility and productivity (Naik et al., 2014). Organic matter has an overwhelming effect on almost all soil properties. A best organic nutrient source not only provides organic matter but also add essential mineral too. The FYM is prepared basically using cow dung, cow urine, waste straw and other dairy wastes. FYM is incorporated in the soil; it has positive effects on plant growth, yield and soil physiochemical properties (Huang et al., 2007). Manures (FYM) applied in the organic form also enhance the bio-availability of macronutrients viz. N, P, K and other micronutrients, and thus increase the concentration of these nutrients in plant tissues (Masti et al., 2003). The panchagavya is an efficient plant growth stimulant that enhances the biological efficiency of crops. It is used to activate soil and to protect the plants from diseases and also increase the nutritional quality of crops. It is used as a foliar spray, as soil application along with irrigation water, seed or seedling treatment. Free living soil bacteria to plant growth are usually referred to as 'PGPR' (Kloepper et al., 1989) or 'yieldincreasing' bacteria (Piao et al., 1992). PGPR have the potential to contribute to the development of sustainable systems (Schippers et al., 1995). PGPR can affect plant growth directly or indirectly. Indirect promotion of plant growth occurs when PGPR lessen or prevent the deleterious effects of one or more phytopathogenic organisms. The direct promotion of plant growth by PGPR generally entails either the bacterium providing a compound that acts as a plant growth regulator or facilitating the uptake of certain nutrients from the environment (Glick, 1995).

Effect of organic nutrients on growth, yield and yield attributes

Growth and yield parameters include plant height, plant girth, leaf length, leaf width, number of leaves, leaf to stem ratio, dry matter yield and green fodder yield. Application of recommended dose of fertilizer $(150: 75: 50 \mathrm{Kg}$ NPK /ha) coupled with FYM at 10 t/ha recorded higher plant height of 186.6 and $190.1 \mathrm{~cm}$ and also leaf area index of 12.14 and 12.42 at harvest during 1995 and 1996, respectively in fodder maize (Nanjundappa et al., 2000). Similarly, the significantly higher leaf area index of 3.82 at 60 DAS and dry matter production of $345 \mathrm{~g} /$ plant at harvest in maize crop were recorded with the application of enriched FYM at $8 \mathrm{t} / \mathrm{ha}+\mathrm{N}(150 \mathrm{~kg} / \mathrm{ha})$ through urea in a field experiment conducted by Debele et al., (2001) on a fine loamy soil at Main Research Station of the University of Agricultural Sciences, Bangalore. Maize plant height $(218.9 \mathrm{~cm})$, leaf area index (3.59) and dry matter (159 g/plant) owed their best expression in the treatment involving application of 100 per cent $\mathrm{N}, \mathrm{P}_{2} \mathrm{O}_{5}$ and $\mathrm{K}_{2} \mathrm{O}$ with FYM at 10 t/ha and was at par with 150 per cent $\mathrm{N}, \mathrm{P} 2 \mathrm{O} 5$ and $\mathrm{K}_{2} \mathrm{O}$ compared to other treatment combinations in a field experiment conducted by Verma et al., (2006) at Instructional Farm, Rajasthan College of Agriculture, Udaipur. Negassa et al., (2001) 
conducted a field experiment in Alfisols to study the effect of integrated use of organic and inorganic fertilizers on growth and yield of maize.

Integrated use of improved fallow (IF) along with application of FYM at $4 \mathrm{t} / \mathrm{ha}$ recorded significantly higher plant height $(312 \mathrm{~cm})$ and was on par with the treatments IF $+55 / 10 \mathrm{~kg}$ $\mathrm{N} / \mathrm{P} \mathrm{ha}{ }^{-1}$ and IF + 2.5 t/ha FYM (311 and 309 $\mathrm{cm}$, respectively) on Alfisol under agroclimatic conditions of Ethiopia. Tetarwal et al., (2011) at Jhalawar noticed that among different treatments, application of RDF + FYM at 10 t/ha resulted in higher plant height $(198.5 \mathrm{~cm})$ and dry matter (150.9 g) in maize, which was at par with application of 150 per cent RDF alone $(207.3 \mathrm{~cm}$ and $149.1 \mathrm{~g}$ of plant height and dry matter, respectively). Application of FYM at $2.5 \mathrm{t} / \mathrm{ha}+$ Eupatorium at $2.5 \mathrm{t} /$ ha resulted in higher plant height $(222.79 \mathrm{~cm})$ in maize compared to rest of the treatments. However, lowest plant height $(195.62 \mathrm{~cm})$ was recorded in control plot (Munda et al., 2011). A field experiment was conducted during kharif season of 2008 and 2009 to study the effect of integrated nutrient management on maize under the Tarai region of West Bengal.

The pooled data of two years revealed that application of 75 per cent NPK through chemical fertilizers + FYM at $2 \mathrm{t} /$ ha resulted in higher plant height $(219 \mathrm{~cm})$ and dry matter accumulation $\left(872.40 \mathrm{~g} / \mathrm{m}^{2}\right)$ at harvest and leaf area index of 2.28, 3.35 and 2.35 at 30, 45 and 60 DAS, respectively (Haque et al., 2012).

Among the different growth parameters of maize, significantly higher plant height $(218.85 \mathrm{~cm})$ and leaf area index (4.73) at harvesting stage were observed with the application of 100 per cent $\mathrm{N}+7.5 \mathrm{t} / \mathrm{ha}$ of FYM. However, this treatment was found to be on par with the treatment comprised of 150 per cent $\mathrm{N}+7.5 \mathrm{t} / \mathrm{ha} \mathrm{FYM}$ with respect to plant height with average plant height of $214.26 \mathrm{~cm}$ (Shilpashree et al., 2012).

Application of 75 per cent RDF (120:60:60 $\mathrm{kg} / \mathrm{ha} \mathrm{N}, \mathrm{P}$ and $\mathrm{K})+\mathrm{FYM}$ at 5 t/ha + biofertiliser (Azospirillum and PSB) resulted in higher plant height $(173.9 \mathrm{~cm})$ and dry matter (251.6 g/plant) of sorghum at harvest on clay soil at Rahuri, Maharashtra (Gawai and Pawar, 2006). Application of 10 tonnes of FYM + $120 \mathrm{~kg}$ N/ha significantly increased growth parameters of wheat viz., plant height $(96.6 \mathrm{~cm})$, effective tillers $/ \mathrm{m}$ row length (104.6) and number of grains/spike (48.9) and was at par with application of 15 tonnes FYM $+100 \mathrm{~kg} \mathrm{~N} / \mathrm{ha}$ in a field experiment conducted at Regional Agricultural Research Sub station, Kargil, Ladhak, Jammu and Kashmir (Ram and Mir, 2006). Kler and Walia (2006) indicated that organic farming with the application of farmyard manure, green manure and incorporation of crop residues proved beneficial in boosting the crop yields in comparison to chemical fertilizers alone. Wheat grain yield was increased by 12.4 per cent in maize-wheat cropping system under organic production system compared to chemical fertilizers.

Application of FYM @ 20 t per ha, recorded significantly higher pod yield and haulm yield over no fertilization and it was comparable with that of 50 per cent RDF in rainy season groundnut (Kachot et al., 2001). Whereas, FYM applied @ $24 \mathrm{t}$ per ha and vermicompost applied@10.8 t per ha in their singular application, found on par with each other with respect to yield and yield parameters.

Further in case of maize, FYM applied @ 24 tonnes per ha recorded higher yield over vermicompost @ 10.8 t per ha (Nanjappa et al., 2001). Application of FYM @ 20 t per ha, recorded significantly higher pod yield and haulm yield over no fertilization and it was comparable with that of 50 per cent RDF in 
rainy season groundnut (Kachot et al., 2001). Whereas, FYM applied @ 24 t per ha and vermicompost applied @ $10.8 \mathrm{t}$ per ha in their singular application, found on par with each other with respect to yield and yield parameters. Further in case of maize, FYM applied @ 24 tonnes per ha recorded higher yield over vermicompost @ 10.8 t/ha (Nanjappa et al., 2001). A long term (15 year) field experiment conducted at Dryland Farming Research Station, Bhilwara, Rajasthan revealed that the application of 100 per cent recommended $\mathrm{N}$ through $\mathrm{FYM}$ to maize in rainy season and 100 per cent $\mathrm{N}$ and $\mathrm{P}_{2} \mathrm{O}_{5}$ through fertilizer in the winter season to mustard recorded the maximum plant height and test weight in both the crop and mustard equivalent yield (Kumpawat, 2004). In soybean, nitrogen supplied through FYM has recorded higher number of pods per plants, seeds per pod, test weight and yield as compared to other sources of nitrogen and it is significantly superior over control (Sabale, 2005).

Application of different organic nitrogen sources significantly influenced the tomato growth and yield. Among the different organic sources, substitution of 100 per cent $\mathrm{N}$ as FYM recorded plant height, number of branches per plant and yield comparable to that of 100 per cent $\mathrm{N}$ as urea (Kannan et al., 2006). Panchagavya applied @ 3 per cent spray at 0,30, 50 days after sowing in case of rice (Ramanathan, 2006) recorded significantly higher grain yield $(5430 \mathrm{~kg} / \mathrm{ha})$ over no panchagavya spray $(4990 \mathrm{~kg} / \mathrm{ha})$ with different organic manure treatments. Similarly panchagavya 3 per cent spray 4 times for bhendi (Lourduraj et al., 2005) augmented the yield level in treatment receiving poultry manure $(10.27 \mathrm{t} / \mathrm{ha})$ which is comparable to inorganic supplementation with pesticide spray (10.39 t/ha). Yadav and Lourdraj (2006) conducted an experiment to evaluate the effect of organic manures (farm yard manure, composted poultry manure, composted coir pith and green leaf manure) and Panchagavya spray on the yield attributes and economics of organically raised rice crop. The findings revealed that application of organic manures and foliar spray of 3\% Panchagavya significantly increased the yield attributes, grain yield and economics. Application of recommended NPK through fertilizers recorded higher grain yield $(5759 \mathrm{~kg} / \mathrm{ha})$, followed by $50 \% \mathrm{~N}$ through composted poultry manure $+50 \% \mathrm{~N}$ through green leaf manure $\left(5717 \mathrm{~kg} \mathrm{ha}^{-1}\right)$ which did not differ significantly. However, application of $50 \% \mathrm{~N}$ through composted poultry manure $+50 \% \mathrm{~N}$ through green leaf manure along with Panchagavya spray recorded significantly higher net returns $\left(17,822 \mathrm{~kg} \mathrm{ha}^{-1}\right)$, followed by recommended NPK through Panchagavya spray ( $15,586 \mathrm{~kg} \mathrm{ha}^{-1}$ ).

Panchagavya sprayed @ 3 per cent four times with poultry manure augmented the yield in okra which was comparable to inorganic nutrient application with pesticide spray (Lourduraj et al., 2005). Improved plant growth parameters in black gram and green gram were observed with application of panchagavya. Cow dung in panchagavya acts as a medium for the growth of beneficial microbes and cow urine provides nitrogen essential for crop growth (De Britto and Girija, 2006). Yadav and Lourduraj (2006a) showed that foliar spray of panchagavya recorded significantly higher values of all the yield parameters of rice compared to without panchagavya spray. Further, milling quality of rice grain and cooking quality improved significantly by panchagavya spray. Somasundaram et al., (2007) concluded that biogas slurry + panchagavya spray proved to be best source as it has recorded higher grain yield of $8.34 \mathrm{t}$ ha- in maize, $3.24 \mathrm{t} / \mathrm{ha}$ in sunflower and $1372 \mathrm{~kg} / \mathrm{ha}$ in green gram. Swaminathan et al., (2007) concluded that application of panchagavya at 3 per cent as 
foliar spray on 15,25 , and 40 days after sowing on black gram recorded the higher grain yield of $1195 \mathrm{~kg} \mathrm{ha}^{-1}$. Kumaravelu and Kadamban (2009) reported that in petriplate culture the greengram seedlings showed significant growth increase at 4 per cent panchagavya treatment, but panchagavya at 6 per cent generally inhibited the plant height, fresh and dry mass of the seedlings. In pot study, 3 per cent panchagavya spray at 10 days after sowing significantly increased the growth of green gram plants. Lateral roots, number of nodules, fresh and dry' mass of the plants increased significantly at 3 and 4 per cent treatment. Ali et al., (2011) in an experiment to study the effect of panchagavya and sanjibani (mixture of cow dung, cow urine and water) liquid organic manure on the yield of green gram (Vigna radiata), chilli (Capsicum frutescens) and mustard (Brassica campestris) found that the sanjibani and panchagavya treated crops recorded higher growth and yield parameters.

Patil et al., (2012) reported that under different combinations of organic manures the combination of enriched compost (1/3) + vermicompost $(1 / 3)+$ glyricidia leaf manure (1/3) equivalent to 100 per cent recommended dose of nitrogen and foliar spray of panchagavya at the rate of 3 per cent at 15 days after sowing and flower initiation has recorded significantly higher grain yield (2400 $\mathrm{kg} \mathrm{ha}^{-1}$ ), haulm yield (3423 $\left.\mathrm{kg} \mathrm{ha}^{-1}\right)$, number of pods per plant (66.38) and 100 seed weight (20.91g) compared to other treatment combinations in chickpea. Significantly higher plant height, number of primary branches per plant: leaf area index (30 DAS) and 50 per cent flowering and yield attributes such as number of pods per plant: number of matured pods per plant, 100 kernel weight, shelling per cent, kernel yield $\left(\mathrm{kg} \mathrm{ha}^{-1}\right)$ : pod yield $(2,304$ $\mathrm{kg} \mathrm{ha-1)}$ and haulm yield (2695 kg ha-) compared to all other treatments. Ramamurthy and Shivashankar (1996) observed that plant height of maize was significantly higher under FYM@15 t/ha than FYM @ 10 t/ha and control. Kader et al., (2002) noticed that inoculation of wheat plants with Azotobacter could result in changes in various growth parameters, such as plant height. The taller plants were observed in different crops inoculated with Pseudomonas, Azospirillum and Azotobacter strains (Siddiqui and Shaukat, 2002). Soleimanzadeh and Gooshchi (2013) reported that the application of Azotobacter had significant effect to increase the plant height. In general, the maximum plant height $(91.9 \mathrm{~cm})$ was obtained at wheat seed inoculation with Azotobacter, while the least value $(88.8 \mathrm{~cm})$ was recorded at without inoculation.

Zaddy et al., (1993) reported that inoculation of single cell suspensions of Azospirillum (prepared with fructose) increased the root surface area, root and foliage dry weight of the maize seedling compared to plants inoculated with malate grown Azospirillum and control. Inoculation of seeds with nitrogen fixing bacteria strains increased fresh and dry weight of plant and also yield (Gomma, 1995). Puertas and Gonzales (1999) reported that the dry matter by tomato plants inoculated with Azotobacter chroococcum and grown in phosphate-deficient soil was significantly greater than non inoculated plants. Observation made by Prasad et al., (2003) indicates that application of $5 \mathrm{t}$ ha-1 vermicompost along with 14 and $10 \mathrm{t}$ ha-1 poultry manure and FYM gave higher dry matter production. Kudtarkar (2005) reported that application of $20 \mathrm{t}$ ha-1 FYM resulted significantly higher number of leaves and dry matter production of maize over $10 \mathrm{t} \mathrm{ha}^{-1}$ FYM as well as control.

Plant growth promoting rhizobacteria (Azotobacter and Azospirillum) had positive effects on yield parameters of corn grown under field conditions (Siddiqui and Shaukat, 
2002). Verma et al., (2003) and Mahala and Shaktawat (2004) from different locations also reported that the application of 5 to $10 \mathrm{t}$ FYM $\mathrm{ha}^{-1}$ produced significantly higher yield attributes viz. cob length, number of grain rows per cob, grain weight per plant and 100grain weight as compared to control. Khan et al., (2008) reported that use of organic manure (FYM, poultry manure, green leaf) on sweet corn field resulted in significant increase of yield attributes i.e., grain number per cob, cob length and diameter. Yasari et al., (2008) reported that application of Azotobacter and Azospirillum increases the oil content of canola seeds and are more suitable for high crop yield, protection from different pathogens and pesticides. Yasari and Patwardhan (2007) revealed that application of Azospirillum and Azotobacter strains increased canola yield (21.19\%), pod per plant (16.07\%), number of branches (12.78\%) and weight of 1000 grain (2.95).

\section{Effect of organic nutrients on soil health}

In maize tried with four residual soil fertility levels viz., FYM at 10, 20, 30 and 40 t/ha, respectively and a control. Experimental results revealed that, the higher uptake of $\mathrm{N}, \mathrm{P}$ and $\mathrm{K} \quad(99.3,16.3$ and $135.6 \mathrm{~kg} / \mathrm{ha}$, respectively) by maize was observed with residual soil fertility level obtained with application of FYM at $40 \mathrm{t} /$ ha compared to preceding levels. The uptake of $\mathrm{N}, \mathrm{P}_{2} \mathrm{O}_{5}$ and $\mathrm{K}_{2} \mathrm{O}(55.5,8.6$ and $79.3 \mathrm{~kg} / \mathrm{ha}$, respectively) was observed in control. Brar et al., (2001). Sharma and Gupta (1998) noticed decrease in soil bulk density to $1.23 \mathrm{mg} / \mathrm{m}^{3}$ with application of 50 per cent $\mathrm{N}, \mathrm{P}_{2} \mathrm{O}_{5}$ and $\mathrm{K}_{2} \mathrm{O}+$ 50 per cent $\mathrm{N}$ through $\mathrm{FYM}$ from initial level of $1.32 \mathrm{Mg} / \mathrm{m}^{3}$ after the harvest of maize crop. Application of organic manures results improvement in maximum water holding capacity of soil was recorded with the application of cow dung manure at $10 \mathrm{Mg} / \mathrm{ha}$ (44 \%) and FYM at $10 \mathrm{Mg} / \mathrm{ha}$ (43 \%) compared to control without these manures (39 \%). Choudhari and Kumar (2013) The application of FYM had significant effect on the available $\mathrm{N}, \mathrm{P}_{2} \mathrm{O}_{5}$ and $\mathrm{K}_{2} \mathrm{O}$ status of the soil after maize harvest. The highest amount of available N, P and K (230.8, 29.6 and 121.3 $\mathrm{kg} / \mathrm{ha}$, respectively) was observed under application of FYM at $10 \mathrm{t} / \mathrm{ha}$ with initial available N, P and K content of 210, 20 and $115 \mathrm{~kg} / \mathrm{ha}$, respectively Jamval (2006). The highest N, P and K content and uptake (Fig. 1) in spinach plant was recorded by foliar application of panchagavya and neem leaf extract followed by treatment panchagavya + glyricidia leaf extract. Whereas, lowest content and uptake of these nutrients in spinach plant was noted in control. (S.E. Shinde, 2018)

Various types of fermented organics prepared from plant and animal origin viz.,dung, urine, butter milk, plant extracts, jaggery etc., come under this category. Which includes panchagavya, jeevamrut, beejamrut, sasyamrut, vermiwash, amritpani etc. Use of fermented organics prepared from cowdung, cow urine, leguminous leaves or vermiwash are effective in promotion of growth and fruiting. Although, these manures may not provide enough nutrients in the area of application, but they help in the quick build up of soil fertility through enhanced activity of soil micro-flora and fauna (Yadav and Mowade, 2004). Presence of naturally occurring, beneficial, effective micro organisms (EMO's), in panchagavya predominantly, lactic acid bacteria, yeast, Actinomycetes, photosynthetic bacteria and certain fungi besides beneficial and proven fertilizers such as Acetobacter, Azospirillum and Phosphobacterium were detected which have the beneficial effect especially in improving soil quality, growth and yield of crops (Xu and $\mathrm{Xu}, 2000)$. Badole and More (2001) reported that application of FYM @ 25 $\mathrm{t} \mathrm{ha}^{-1}$ recorded higher population of 
Azotobacter $\left(0.38 \times 10^{3}\right.$ cells $\mathrm{g}^{-1}$ soil $)$, Rhizobium (10.5 $\times 10^{3}$ cells $\mathrm{g}^{-1}$ soil), Actinomycetes (14.9 × $10^{4}$ cells soil), fungi $\left(6.7 \times 10^{3}\right.$ cells $\mathrm{g}^{-1}$ soil $)$, bacteria $\left(62.5 \times 10^{4}\right.$ cells $\mathrm{g}^{-1}$ soil $)$ and PSB $\left(29.1 \times 10^{4}\right.$ cells $\mathrm{g}^{-1}$ soil) as compared to control. Ali et al., (2011) observed that after one year of organic practice involving panchagavya and sanjivini $\mathrm{pH}$ and $\mathrm{EC}$ became close to neutral $(\mathrm{pH}$ from 6.8 to 7.0 and EC from to $0.3 \mathrm{~m} \mathrm{mhos}$ ), organic carbon content increased from 0.71 to 1.1 per cent, available phosphorus increased by more than 3 times and potassium by more than 2 times.

Govindaraju and Reddy (2011) reported the increment in the population of phosphorus solubilising bacteria Azospirillum, Azotobacter and Rhizobium after three years of conversion to organic farming the average increase in PSBs was from 1.7 to $3 \mathrm{~g} \mathrm{x} 10^{6}$ cfu per g soil. Similarly: Azospirillum, Azotobacter, and Rhizobium increment was 2.1 to 3.1, CS to and 0.4 to per soil, respectively.

Dutta and Podile, 2010 revealed that PGPR which intern promotes the soil biological characters and make more convenient for the crop growth((Fig.2) ; Higher population of total bacteria (58 $\mathrm{cfu} \times 10^{5}$ soil), nitrogen fixers (45 cfu x $10^{3} \mathrm{~g}^{-1}$ soil) and P solubilizers (32 cfu $\times 10^{3}$ soil) were observed with cow urine and panchagavya spray as compared to without cow urine and panchagavya spray (Devakumar et al., 2010).

Latha (2013) with the application of EBDLM @ 25 (groundnut), 125 (onion) $\mathrm{kg} \mathrm{N}$ eq. $\mathrm{ha}^{-1}+$ three sprays of 3 per cent panchagavya in groundnut-onion cropping sequence recorded significantly higher available of nitrogen, phosphorus, potassium and sulphur in soil at harvest Pradeep Gopakkali (2013) whereas, with application of EBDLM at 125 (chilly) / 100 (onion) kg N/ha- + three sprays of 3 per cent panchagavya in groundnut-onion cropping sequence recorded significantly higher available of nitrogen, phosphorus, potassium and sulphur in soil at harvest. Lavanya et. at (2016) revealed that maximum population of general bacteria, fungi, Actinomycetes, N-fixers, Pseudomonas and PSB were observed to be $40 \times 10^{5}$ cfu, $32 \times 10^{3}$ cfu $15 \times 10^{4}$ cfu, $21 \times 10^{5}$ cfu $3 \times 10^{5}$ cfu and $25 \times 10^{5}$ cfu g $^{-1}$ respectively in the soil treated with jeevamrutha at 4001 tr acre $^{-1}$ and 7.5 per cent panchagavya $\mathrm{m}$ field bean when compared to without jeevamrutha and panchagavya treated soil $\left(5 \times 10^{5} \mathrm{cfu} 3 \times 10^{4} \mathrm{cfu}\right.$ $\mathrm{g}^{-1}$, cfu $8 \times 10^{5}$ cfu g $^{-1} 10 \times 10^{5}$ cfu and $10 \times 10^{5}$

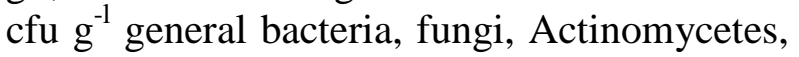
$\mathrm{N}$-fixers, Pseudomonas and PSB respectively)

The combined use of organic amendments (MSWC, RSC and GEC) along with 25\% RDF increases dehydrogenase activity than unfertilized control plot because of more substrate availability. Meena et al., (2016).

Application of farm yard manure at $16 \mathrm{t} / \mathrm{ha}$ was recorded significant decrease in the soil bulk density ( 1.55 to $1.33 \mathrm{~g} / \mathrm{cm}-3)$ and $\mathrm{pH}(7.5$ to 7.0) over other organic and inorganic nutrient sources. Mahamood et al., (2017) \& Shwetha (2008) in wheat crop combined application of fermented organics viz., beejamrut, jeevamrut, panchagavya along with organics such as compost, vermicompost, green leaf manure to Vertisol recorded higher soil biological activity. Similarly, dehydrogenase activity was higher with combined application of organics and fermented organics than their individual applications and RDF + FYM.

The highest dehydrogenase activity of 34.84 $\mu \mathrm{g}$ TPF $\mathrm{g}^{-1}$ soil per day in soil was observed with compost + vermicompost + green leaf manure + jeevamrut + beejamrut and was on par with treatment receiving vermicompost + green leaf manure + jeevamrut + beejamrut + panchagavya. 


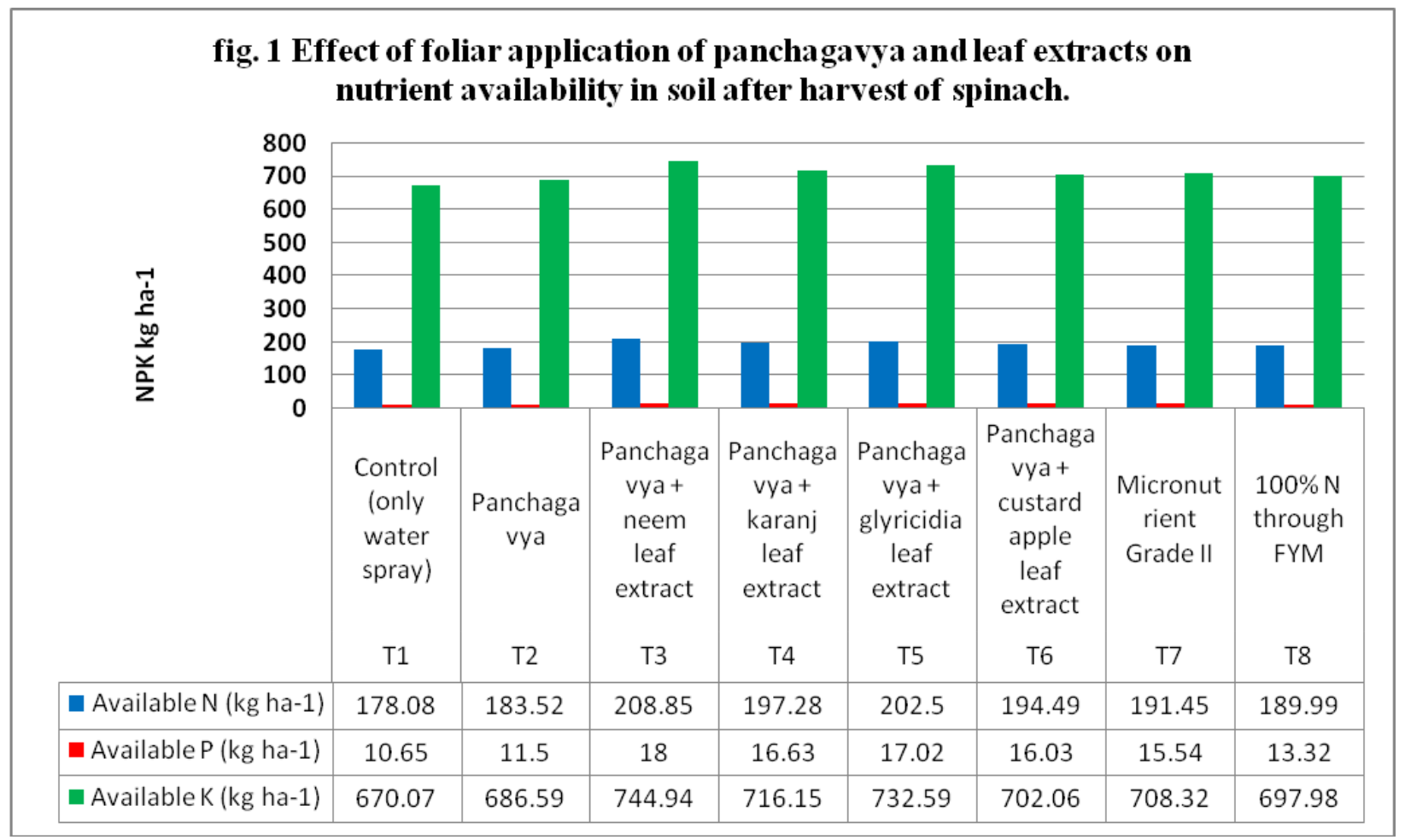

Source : S.E. Shinde M.Sc Thesis

Fig.2 Effect of root exudates on rhizosphere microorganisms, including PGPR. Host roots, indigenous microorganisms, and PGPR are intricately interrelated. Root exudates alter microbial population directly or indirectly by altering the soil nutrient and physical status.

(source: Dutta and Podile, 2010)

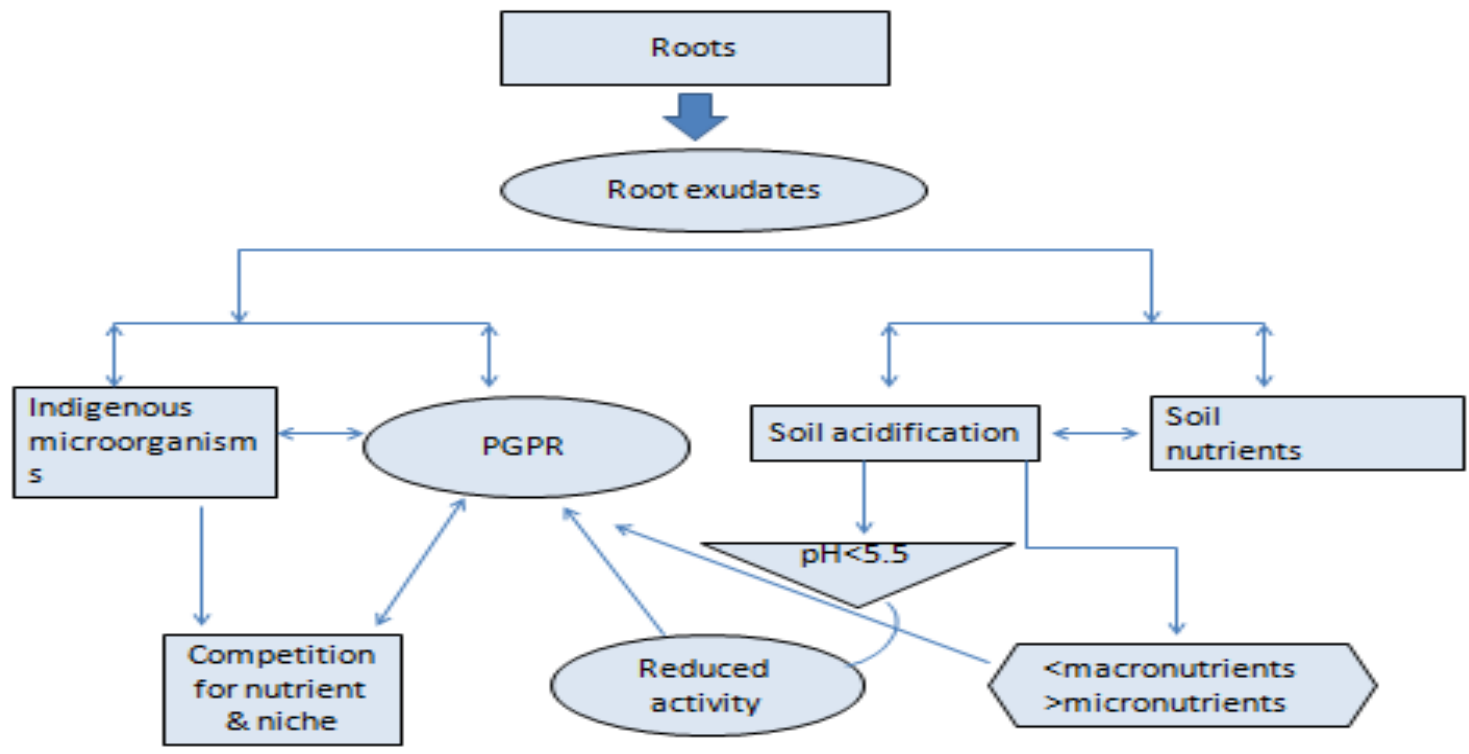




\section{Effect of organic nutrients on plant quality}

Application of N: $\mathrm{P}_{2} \mathrm{O}_{5}$ 112:45 + Farm yard manure $1000 \mathrm{~kg} \mathrm{ha}^{-1}$ which results significant decrease in the rice fibre content, higher crude protein content and higher total ash content. Ahmad et al., (2011) A field investigation was conducted to study quality of maize as influenced by application of fertilizers and manures. The results revealed that application of 100 per cent NPK + FYM at 10 t/ha resulted in higher crude protein and starch content in maize grains (12.19 and 60.20 per cent, respectively) compared to application of chemical fertilizers alone. Kamalakumari and Singaram (1996). The uptake of N, P, K, Ca, $\mathrm{Mg}$ and $\mathrm{S}$ were significantly higher in the grain and straw of finger millet with $50 \% \mathrm{~N}$ inorganic +100 per cent $\mathrm{PK}+50$ per cent $\mathrm{N}$ through enriched urban compost as compared to $100 \%$ NPK + FYM @ 10 ton ha ${ }^{-1}$. Punitha and Prakasha (2015). Kamalakumari and Singaram (1996). Application of 100 per cent NPK + FYM at $10 \mathrm{t} \mathrm{ha}^{-1}$ resulted higher crude protein and starch content in maize grains (12.19 and $60.20 \%$, respectively) compared to application of chemical fertilizers alone.Hannah et al., (2005) observed that the panchagavya spray produced tastier banana fruits at the Agricultural College Research Institute, Tamil Nadu. The Panchagavya solution sprayed @ 3 per cent resulted in improvement in quality of fruits viz., total soluble sugars, and total sugars while, it reduced the negative quality characters like acidity and ascorbic acid content.

Mohan (2008) reported the effect of three organic growth promoters on quality of two vegetable crops, brinjal (Solanum melongena) and tomato (Lycopersicon esculentum) and study resulted that the glycoalkaloid levels were lower under organic growth parameter treatments when compared to the control. Treatments with Bokashi showed the lowest glycoalkaloid contents.Theunissen et al.,
(2010) reported that the high percentage of humic acids in vermicompost contributes to plant health, as it promotes the synthesis of phenolic compounds such as anthocyanins and flavonoids which may improve the plant quality. Dange et al., (2011) reported the effect of organic and inorganic fertilizers on quality parameter of Spinach and study resulted that significantly highest moisture content noticed in control. The lower moisture content in treatment receiving combination of inorganic fertilizers and organic manure might due to higher dry matter accumulation as result increased photosynthetic activity. Bharad et al., (2013) studied the quality parameters of spinach i.e. leaf chlorophyll content, leaf moisture and leaf ascorbic acid content and recorded highest in one cutting an $50 \mathrm{~kg} \mathrm{~N} \mathrm{ha}^{-1}$ applied through urea. Jagtap et al., (2013) noticed that foliar application of vermiwash $20 \%$ and gibberlic acid $50 \mathrm{ppm}$ on fenugreek significantly increase amount of total carbohydrates, soluble protein and activities of soluble enzymes like amylase, catalase and protease thus improves phytochemical values. Caliskan et al., (2014) reported that.

The values of vitamin $\mathrm{C}$ content of lettuce grown in the organic production systems were higher than these of the conventional production system.Raghavendra et al., (2014) observed that the panchagavya contains several nutrients i.e. macronutrients like $\mathrm{N}, \mathrm{P}$, $\mathrm{K}$ and micronutrients which are required for various amino acids, vitamins, growth regulators like Auxins and gibberellins. Shailaja et al., (2014) studied that the impact of Panchagavya on the leaf quality of spinacia oleracea and study showed that the leaf contents like vitamin, minerals and protein are more in quantity with Panchagavya treatment. Jandaik et al., (2015) noticed that the application of cow urine significantly increase protein, carbohydrates and chlorophyll content in okra and methi. 


\section{Effect of organic nutrients on economics}

Somasundaram (2003) opined that three per cent panchagavya spray at 15, 25, 40 and 50 DAS to green gram was an effective low cost technology. While, Shete et al., (2011) recorded higher net returns of 21,357 ha ${ }^{-1}$ and B: C ratio of 3.46 with 5 ton FYM ha ${ }^{1}$.Panchagavya spray recorded significantly higher gross returns (Rs.37608 ha ${ }^{-1}$ ), net returns (Rs. 17,822 ha ${ }^{-1}$ ) and benefit cost ratio (1.92) as compared to without panchagavya spray (Rs.34, 612 ha $^{-1}$, Rs.15,586 ha ${ }^{-1}$ and 1.84, respectively).

Application of 50 per cent $\mathrm{N}$ through composted poultry manure +30 per cent nitrogen through green leaf manure along with panchagavya spray recorded higher net returns (Rs.17, 822 ha $^{-1)}$. Deshmukh et al., (2012) revealed that application of 100 per cent RDN through vermicompost, FYM and compost along with jeevamrutha found beneficial in increasing economic returns (Rs. 78,501 ha ${ }^{-1}$ and Rs. 71,369 ha ${ }^{-1}$, respectively) and B: C (2.61, 2.82 and 2.82, respectively) of soybeanwheat cropping sequence under irrigated condition.

Higher net return and B: C ratio was recorded with application of FYM and coir pith compost along with panchagavya (3 to 6 per cent) spray for capsicum. Similarly, application of jeevamruta cow urine and panchagavya (3 to 6 per cent) spray to capsicum recorded higher net return and B: C ratio during Kharif 2008 and summer 2009 (Boraiah, 2013).

Shailaja et al., (2014) revealed that the panchagavya is a mixed culture of naturally occurring beneficial microbes mostly lactic acid bacteria (Lactobacillus), yeast (Saccharomyces), actinomyces (Streptomyces), photosynthetic bacteria (Rhodopsuedomonas) and certain fungi
(Aspergillus) which promotes the grov.th and yield in different crops and provides high ratio. So, panchagavya can be an effective orgamc grouth-promoter for small and marginal farmers.

The economic analysis showed that in both the rice varieties (Masura and Hamsa) benefit-cost ratio was better with application of panchagavya being 3.39 in Masura variety and 3.0 in Hamsa as compared to 1.09 and 0.6 in chemical methods of rice production respectively (Uma Amareshwari and Sujathamma: 2014b). Siddappa (2015) reported that higher gross return, net return and $\mathrm{B}: \mathrm{C}$ ratio were recorded with application of FYM 200 per cent $\mathrm{N}$ equivalent + jeevamrutha@1500 1 ha ${ }^{-1}$ (Rs. 56,635 ha ${ }^{-1}$, Rs. $30,430 \mathrm{ha}^{-1}$ and 2.16 , over FYM at 100 percent $\mathrm{N}$ equivalent + no jeevamrutha application (Rs. 30,745 ha ${ }^{-1}$ Rs. 10,055 ha $^{-1}$ and 1.49 , respectively).

Organic nutrient management with the components of panchagavya, Plant Growth Promoting Rhizobacteria (PGPR, Farm Yard Manure (FYM) which intern support for the maximum yield in fodder production along with minimum cost of production when these are used in optimum combination and also enhance the soil fertility status like available nutrients, microbial status etc. in future area these can be used to enhance the nutrient content of the fodder crop which will help the livestock animal health and full fill the deficiency gap, increase the fodder production with lesser cost because the inputs are available in on farm, increases the soil physico-chemical properties like water holding capacity, soil structure, soil organic carbon, regulate the soil $\mathrm{pH}$, etc. and now a days there is huge demand for the organic milk and for that there is no any specific standards hence it will be a future for the organic milk production to make specific standards. 
The milk production economics will boost up by this to minimise the cost of production of fodder and with higher milk prize for organic milk.

\section{References}

Abele, U. (1978). Investigations on the ecotoxicological effect of residues of cleaning and disinfecting products from livestock on soil and groundwater applied to farmland with liquid manure, Plant yield and plant quality. KTBL Schriftenr 224: 1134.

Ahmad, A.H., Wahid. A., Khalid, F., Fiaz, N and Zamir, M. S. I. (2011). Impact of organic and inorganic sources Of nitrogen and phosphorus fertilizers on growth, yield and quality of forage oat (avena sativa L.). Cercetări Agronomice in Moldova. 147(3): pp 39-49.

Ali, M. N., Ghatak, S. And Ragul, T.(2011). Biochemical analysis of panchagavya and sanjibani and their effect in crop yield and soil health. J. Crop and Weed 7(2): 84-86.

Anonymous, (2001). Drafts report of the working group on Animal husbandry and dairying for 5 year plan (2002-07), Govt. of India, Planning Commission, pp. 122 123.

Badole, S. B. And More, S. D. (2001). Residual effect of integrated nutrient management on yield of groundnut. J. Maharashtra Agric. Univ., 26(1): 109- 110.

Bharad, S. G., Korde, S. D., Satpute P, and Baviskar, M. N. (2013). Effect of organic manures and number of cuttings on growth, yield and quality of Indian spinach. Asian Journal of Horticulture. 8(1): 60-64.

Brar, B. S., Dhillon, N. S and Chhina, H. S. (2001). Integrated use of farmyard manure and inorganic fertilizers in maize (Zea mays). Indian J Agric Sci 71: 605-07.

Caliskan, S., Yestisir, H. and Karanlik, S. (2014). Combined Use of Green Manure and Farmyard Manure Allows Better Nutrition of Organic Lettuce. Not Bot Horti Agrobo, 2014, 42(1):248-254.
Choudhary, K. M., Patel, M. M. and Pagar, R.D. (2014) Effect of foliar application of panchagavya and leaf extracts of endemic plants on groundnut (Arachis hypogaea) Agricultural Research Communication Centre 37(2): 223 - 226.

Dange, M. B., Bhosle. A. M and Barkule, S. R. (2011). Effect of organic and inorganic fertilizers on growth, yield and quality of palak. International Journal of Plant Science., 6(1) : 91-94.

Dar, A. N., Khan, H. U. and Ganai, N. A. (2006). Improvement and management of grass lands in the Hill and Mountain State of $\mathrm{J} \& \mathrm{~K}$ for Sustainable live stock iii development/ http://www.greaterkashmir.com / news /2006/Sep/ 4/sustainable- livestockdevelopment-i-2.asp

De Britto, J. A. and Girija, S. L. (2006). Investigation on the effect of organic and inorganic farming methods on blackgram and greengram. Indian J. Agric. Res., 40(3): 204-207.

Deshmukh, J. P., Potkile, S. N., Shingrup, P. V. And Patil, S. P. (2012), Effect of organic nutrient management on soybean-wheat crop sequence under irrigated condition. Extended Summaries Vol 2: Third Int. Agron. Cong., p. 549- 550.

Devakumar. N., Rao, G. G. E., Shubha, S., Imrankhan, Nagaraj And Gowda, S. B. (2008), Activities of Organic Farming Research Centre, Navile, Shimoga, University of Agricultural Sciences, Bengaluru, Karnataka, India.

Dutta, S and Podile, A. R. (2010). Plant Growth Promoting Rhizobacteria (PGPR): the bugs to debug the root zone. Critical Reviews in Microbiology, 36(3): 232-244.

Gawai, P. P. and Pawar, V. S. (2006). Integrated nutrient management in sorghum (Sorghum bicolor) - chickpea (Cicer arietinum) cropping sequence under irrigated conditions. Indian journal of Agronomy. 51(10): $17-20$.

Glick, B.R. (1995). The enhancement of plant growth by free-living bacteria. Can. J. microbial 41:109-117. 
Gomma, A. M. H. (1995). Response of certain vegetable crop to biofertilizer. Ph.D.Thesis, Faculty of Agriculture, Cairo University, Egypt 201p.

Govindaraju, C. And Reddy, V. C. (2011), Developing organic package of practices for yield maximization of rainfed finger millet. Ann. Prog. Report, Research Institution Organic Farming, University of Agricultural Sciences, Bangalore.

Hannah, K.A., Pandian, B.J. and Selva Rani. (2005), Panchagavya spray produces tastier banana fruit. Agrobios Newslet., 4(1) pp. 45.

Haque, S., Parta, P. S. and Sana, A. (2012). Growth attributes, con yield and economics of maize (Zea mays L.) cultivars as affected by integrated nutrient management under Terai region of West Bengal. Indian J. Agric. Res., 46 (1) : 42-47.

Huang, B., Sun, W. Z., hao, Y. Z., Hu, J. R., Yang, Z., Zou, F. Ding and Su, J. 2007. "Temporal and spatial variability of soil organic matter and total nitrogen in an agricultural ecosystem as affected by farming practices." Geoderma. 139: 336345.

Jagtap, D. K., Gaikwad, R. B., Thakare, U. G. and Jakhi, P. S. (2013). Vermiwash and gibberellic acid on seed germination in fenugreek (trigonella foenum-graecum L.). Int. J. Biotech Biosci, ISSN 2231-0304, 3 (4) : 230-234.

Jamwal, J. S. (2006). Effect of integrated management in maize (Zea mays L.) on succeeding winter crops under rainfed condition. Indian journal of Agronomy. 51(1):14-16.

Jandik, S, Kumar, V. and Thakur, P. (2015) a. Vermiwash : Plant growth enhancer and antifugal agent. International J. Ext Res. 2: 38-41.

Kachot N. A., Malavia, D. D., Solanki, R. M. and Sagarka, B.K. (2001). Integrated nutrient management in rainy-season groundnut (Arachis hypogea). Indian $J$. Agron. 46 (3): 516-522.

Kader, M.A., M.H. Mian and M. S. Hoque. (2002). Effects of Azotobacter inoculants on the yield and nitrogen uptake by wheat. J. Biol. Sci. 4: 259-261.

Kamalakumari, K. and Singaram, P. (1996). Effect of continuous application of FYM and NPK on fertility status of soil, yield and nutrient uptake in maize. Madras Agric. J., 83 (3) : 181-184.

Kamalakumari, K. and Singaram, P. (1996a), Quality parameters of maize as influenced by application of fertilizers and manures. Madras Agric. J., 83 (1) : 32-33.

Kannaiyan, K., (2000) Biofertilisers- Key factorsn in organic farming. The Hindu Survey of Indian Agriculture pp: 165-173.

Kannan P, Saravanan A and Balaji T. (2006). Effect of organic farming on tomato yield and quality. Crop Res., Hisar, 32 (2): pp 196-200.

Khan, H. Z., Malik, M. A. and Saleem, M. F. (2008). Effect of rate and source of organic material on the production potential of spring maize (Zea mays L.). Pakistan J. Agric. Sci. 45(1): 40-44.

Kler, D. S. and Walia, S. S. (2006). Organic, inorganic and chemical farming in wheat (Triticum aestivum) under Maize (Zea mays)- Wheat cropping system. Indian J. Agron. 51 (1): 6-9.

Kloepper, J. W., Lifshitz, R., Zablotowicz, R.M. (1989). Free- living bacterial inocula for enhancing crop productivity. Trends Biotechnol. 7, 39-43.

Kudtarkar, U.S. (2005). Effect of polythene mulch, levels of organic manure and fertilizer on the performance of rabi groundnut (Arachis hypogeal L.). M.Sc. Thesis, Kokan Krishi Vidyapeeth, Dapoli, District Ratnagiri (M.S.). 60-64p.

Kumaravelu, G. And Kadamban, D. (2009), Panchagavya and its effect on the growth of Greengram cultivar K-851. Int. J. Plant Sci., 4(2): 409-414.

Kumpawat, B. S. (2004). Integrated nutrient management for maize (Zea mays L.) Indian mustard (Brassica juncia L.) cropping system. Journal of the Indian Society of Agronomy. 49(1): 18-21.

Latha, H. S. (2013), Development of organic production techniques for ground nut onion 
sequence cropping system. Ph.D. Thesis, University of Agricultural Sciences, Bangalore.

Lavanya, G., Devakumar N., Latha, B., and Ramesh Kumar, C. (2016), Influence of Jeevamrutha and Panchagavya on beneficial soil microbial population in organic field bean. Natnl. Conf. on Sust. Self Sufficient Prodn. of Pulses through an Integrated Approach. Bengaluru. p. 98.

Lourduraj, Christopher, A., Boomi, Raj, K. and Paneer Selvam, S. (2005). Yield attributes and yield of Okra as influenced by organic manures. Proc. Sem. Org. Agric. Peninsular India, OASIS, Coimbatore, pp.187-188.

Mahala, H. L. and Shaktawat, M. S. (2004). Effect of sources and levels of phosphorus and FYM on yield attributes, yield and nutrient uptake of maize (Zea mays L.). Annals ofAgriculture ResearchNew Series, 25(4): 571-574.

Mahmood, M., Imran, A., Umair, A., Shazad, T., Sabir, H., Muhammad, S., Muhammad, A and Sami, U. (2017). Effects of organic and inorganic manures on maize and their residual impact on soil physico-chemical properties. Journal of Soil Science and Plant Nutrition, 17 (1), 22-32.

Masti, T., Lithourgidis, A. S. and Gagianas, A. (2003). "Effect over of injected liquid Cattle manures on growth and yield of winter wheat and soil characteristics." Agron. J. 95: 592 -599.

Meena, M. C., Dwivedi, B. S., Singh, D., Sharma, B. M., Kumar, K., Singh, R. V., Kumar, P. and Rana, D. S. (2016). Effect of integrated nutrient management on productivity and soil health in pigeonpea (Cajanus cajan) -wheat (Triticum aestivum) cropping system. Indian Journal of Agronomy, 57: 333-337.

Mohan, B. (2008). Evaluation of organic growth promoters on yield of dryland vegetable crops in India, Journal of Organic Systems. 3(1) Pp.23-36.

Munda, G. C., Mokidul, I. and Nath, L. K. (2011). Integrated nutrient management approach for enhancing productivity and economics of maize (Zea mays L.) - Toria (Brassica campestris L.) cropping system. Agric. Sci. Digest, 31 : 188-192.

Naik, V. R., Patel, P. B. and Patel, B. K. (2014). Study on effect of different organics on yield and quality of organically grown onion. The Bioscan. 9(4): 1499-1503.

Nanjappa, H. V., Ramchandrappa, B. K. and Mallikarjuna, B. O. (2001). Effect of integrated nutrient management on yield and nutrient balance in maize (Zea mays). Indian J. Agron., 46 (4) : 698-701.

Nanjundappa, G., Shivaraj, B., Shridhar, S. and Janarjun, S. (2000). Effect of organic and inorganic sources of nutrients alone and in combination on the growth and yield of fodder maize. Mysore J. Agric. Sci., 34 : 247-250.

Negassa, W., Negisho, K., Friesen, D. K., Ransom, J. and Yadessa, A. (2001). Determination of optimum farmyard manure and NP fertilizers for maize on farmers' fields. Seventh Eastern and Southern African Regional Maize Conference 11-15th Feb., 2001, pp. 387393.

Patil, S.V., Halikatti, S. I., Hiremath, S. M., Babalad, H. B., Sreenivasa, M. N., Hebsur, N. S. and Somanagouda, G. (2012). Effect of organics on growth and yield of Chickpea (Cicer arietinum L.) in vertisols. Karnataka. J. Agric. Sci., 25(3): 326-331.

Patten C. L., Glick B. R. (2002) Role of Pseudomonas putida indole acetic acid in development of the host plant root system. Appl Environ Microbiol. ;68:37953801.

Piao, C. G., Tang, W. H., Chen, Y. X. (1992). Study on the biological activity of yieldincreasing bacteria. China J. Microbiol. 4, $55-62$.

Pradeep Gopakkali, (2013). Development of liquid organic manures and their evaluation for organic production of Chilli and Onion. Ph.D. Thesis, University of Agricultural Sciences, Bangalore.

Prasad, B. K.; Singh, D. N. and Singh, S. N. (2003). Effect of long term use of fertilizer, lime and manures on growth and yield of 
sweet corn. Journal of Indian Society of Soil Science, 34: 271-274.

Puertas, A., Gonzales, L. M. (1999). Aislamiento de cepasnativas de Azotobacter chroococcum en la provincial Granmayevaluacion de suactividadestimuladora en plantulas de tomate. Cell Mole. Life Sci. 20: 5-7.

Punitha and Prakasha (2015). Influence of enriched urban solid waste compost on soil properties, yield and uptake of nutrients in cereal - pulse cropping systems. Thesis submitted to the university of agricultural sciences, bengaluru.

Raghavendra, K. V., Gowthami, R., Shashank, R., Harish Kumar, S. (2014). panchagavya in organic crop production. Popular Kheti., 2(2):233-23

Ram, T. and Mir, M. S. (2006). Effect of integrated nutrient management on yield and yield-attributing characters of wheat (Triticum aestivum). Indian J. Agron., 51 (3) : 189-192.

Ramamurthy, V. and Shivashanker, K. (1996). Residual effect of organic matter and phosphorus on growth, yield and quality of maize (Zea mays L.). Indian. J. Agron. 41(2): 247-251.

Ramanathan, K. M. (2006). Organic farming for sustainability. J. Indian Soc. Soil Sci. 54 (4): 418-425.

Sabale, R. N. (2005). Effect of sources of nitrogen on yield of soybean. $J$. Maharashtra Agric. Univ., 30 (3): 262263.

Schippers, B., Scheffer, R. J., Lugtenberg. And Weisbeek, P. J. (1995). Biocoating of seed with plant growth promoting rhizobacteria to improve plant establishment. Outlook Agr. 24, 179-185.

Shailaja, B., Ipsita M., Srihima G., Vikram J. S And Swathi, K. (2014).Panchagavya an ecofriendly insecticide and organic growth promoter of plants. Int. J. Adv. Res., 2(11): 22-26.

Sharma, M. P. and Gupta, J. P.(1998). Effect of organic materials on grain yield and soil properties in maize (Zea mays L.) wheat (Triticum aestivum) cropping system.
Indian j. Agric. Sci., 68 : 715-717.

Shete, P. G., Thanki, J. D., Baviskar, V. S. and Bhoye, K. P. (2011). Yield, nutrient uptake and economics of Greengram as influenced by land configurations and FYM levels. Green Farming, 2(4): 425- 427.

Shilpashree, V. M., Chidanandappa, H. M., Jayaprakash, R. and Punitha, B. V. (2012). Influence of integrated nutrient management practices on productivity of maize crop. Indian J. Fund. Appl. Life Sci., 2 (1): 45-50.

Shinde, E. S. (2018). Effect of foliar application of panchagavya and leaf extract's on nutritional quality of spinach. M. Sc Thesis parabhani, Maharashtra.

Shwetha, B. N. (2001). Effect of nutrient management through organics in soybean wheat cropping system. M. Sc. (Agri)Thesis, University of Agricultural Sciences, Dharwad.

Siddappa, (2015). Use of jeevamrutha and farm yard manure on growth and yield of field bean (Dolichos lablab L.). M.Sc. (Agri.) Thesis submitted to University of Agricultural Sciences, Bangalore, Karnataka, India.

Siddiqui, I. A. and S. S. Shaukat. (2002). Mixtures of plant disease suppressive bacteria enhance biological uptake control of multiple tomato pathogens. Biology and Fertility of Soil. 36(4): 284-297.

Soleimanzadeh, H. and Gooshchi, F. (2013). Effects of Azotobacter and nitrogen chemical fertilizer on yield and yield components of wheat (Triticum aestivum L.). World Applied Sci. J. 21 (8): 11761180.

Somasundaram, E., Sankaran, N., Meena, S., Thiyagarajan, T. M., Chandaragiri, K. And Panneerselvam, S. (2007). Response of greengram to varied levels of Panchagavya (organic nutrition) foliar spray, Madras Agric. J., 90(2): 169-172.

Somasundaram, E., Sankaran, N., Meena, S., Thiyagarajan, T. M., Chandaragi, K. K. And Panneerselvam, S. (2003). Response of greengram to varied concentrations of panchagavya (organic nutrition) foliar 
application. Madras Agric. J., 90: 169-72.

Swaminathan, V. and Vijayalakshmi, V. (2007). Panchagavya: Boon to organic farming. Int. book distributing Co., India.

Tetarwal, J. P., Baldev, R. and Meena D. S. (2011). Integrated nutrient management on productivity, profitability, nutrient uptake and soil fertility in rainfed maize

(Zea mays L.) Indian J. Agron. 56(4): 373-376.

Theunissen, J., Ndakidemi, P. A. and Laubsche, C. P. (2010). Potential of vermicompost produced from plant waste on the growth and nutrient status in vegetable production. International Journal of the Physical Sciences Vol. 5(13), pp. 1964-1973.

Uma Amareswari, P. and Sujathamma, P. (2014). A study on the effect of different organic supplements on the ascorbic acid and riboflavin content of French bean (Phaseolus vulgaris). Int. J. of Emerging Tech. in Computational and Appld. Sci., 8(3): 269-271.

Uma Amareswari, P. And Sujathamma, P. (2014). Jeevamrutha as an alternative of chemical fertilizers in rice production. Agric. Sci. Digest., 34(3): 240 - 242.

Verma, C. P., Kedar Prasad, Singh, H. V. and Verma, R. N. (2003). Effect of soil conditioners and fertilizers on yield and economics of maize (Zea mays L.) in maize-wheat sequence. Crop Research. 25(3): 449-453.

Verma. A., Nepalia, V. and Kanthaliya, P. C. (2006). Effect of integrated nutrient supply on growth, yield and nutrient uptake by Maize (Zea-may L.) wheat (Triticum aestivum L.) cropping system. Indian journal of Agronomy.51 (1):3-6.

$\mathrm{Xu}, \mathrm{H}$. L. and $\mathrm{Xu}, \mathrm{H}$. L., 2000, Effect of microbial inoculants and organic fertilizers in the growth, photosynthesis and yield of Sweet corn (Zea mays L. saccharata), J. Crop Prod., 3(9): 183-214.

Yadav, A. K. and Mowade, S. M., (2004). Organic manures and compost. In : Organic Farming - A Ray of Hope for Indian Farmer.

Yadav, B. K and Lourdraj, C. A. (2006). Effect of organic manures and panchagavya spray on yield attributes and economics of rice (Oryza sativa)_Crop Research, 31: 1-5.

Yadav, B. K. And Lourduraj, C. A. (2006b), Effect of organic manures and panchagavya spray on Rice (Oryza sativa L.) quality. Crop Res., 31(1): 6-10.

Yadav, B. K., And Lourduraj, C. A., (2006a). Effect of organic manures and panchagavya spray on yield attributes, yield and economics of Rice (Oryza sativa L.) quality. Crop Res., 31(1): 1-5.

Yasari, E. and Patwardhan, A. M. (2007). Effects of Azotobacter and Azospirillium inoculations and chemical fertilizers on growth and productivity of canola. Asi. $J$. Plant. Sci., 6(1): 77-82.

Yasari, E., Esmaeli, A., Pirdashti, A. M. and Mozafari. S. (2008). Azotobacter and Azospirillum inoculants as bio-fertilizers in canola (Brassica napus L.) cultivation. Asian J. Plant Sci. 7(5): 490-494.

Zaddy E., Perevolosky A. and Okon Y. (1993). Promotion of plant growth by inoculation with aggregated and single cell suspension by Azospirillum brasilense. Soil Biol. Biochem. 25: 819-823.

\section{How to cite this article:}

Santosh Onte, Magan Singh, V. K. Meena, Sanjeev Kumar, B. L. Meena and Susanta Dutta 2019. Organic Nutrient Management in Context to Sustainable Fodder Production: A Review. Int.J.Curr.Microbiol.App.Sci. 8(09): 2434-2449. doi: https://doi.org/10.20546/ijcmas.2019.809.282 